HTTP://DX.DOI.ORG/10.12775/SZHF.2016.044

\author{
AgnieszKa Wesolowska
}

Uniwersytet Śląski, Katowice, Polska

Aletheia2@INTERIA.PL

\title{
Fenomenologiczne ujęcie podmiotowości a kryzys człowieczeństwa
}

\begin{abstract}
Bycie samodzielnym myślicielem, autonomicznym filozofem wypełnia wola uwolnienia się od wszystkich przesądów (Vorurteile), wymaga od niego zrozumienia, że wszystko, co u niego zrozumiałe samo przez się, to przesądy [...] i, że dotyczy to także tego wielkiego zadania, tej idei, która zwie się "filozofią «".
\end{abstract}

Celem artykułu jest pokazanie, że Husserl, formułując diagnozę ogólnego kryzysu, w szczególności kryzysu nauk, które ulegają różnorakim przesądom oraz kryzysu filozofii uwikłanej w liczne trudności, ujawnia płynące stąd konsekwencje prowadzące do kryzysu samego europejskiego człowieczeństwa. Jeżeli chodzi o kryzys człowieczeństwa, to jest on stałym motywem Husserlowskiej filozofii i polega na zapoznaniu kwintesencji podmiotowości,

${ }^{1}$ E. Husserl, Die Krisis der europäischen Wissenschaften und die transzendentale Phänomenologie. Eine Einleitung in die phänomenologische Philosophie, hrsg. von W. Biemel, [in:] Husserliana - Edmund Husserl, Gesammelte Werke, Bd. 6, Den Haag 1962, s. 73. Cyt. za polskim przekładem Kryzysu... - E. Husserl, Kryzys nauk europejskich i fenomenologia transcendentalna, przeł. S. Walczewska, Toruń 1999, s. 78. 
jaką jest jej transcendentalny charakter, zapoznaniu, którego konsekwencją okazuje się reifikacja człowieczego „ja”. W związku z ideą kryzysu człowieczeństwa Husserl ukazuje, że: po pierwsze, nauki pomimo sukcesów trwają w zaślepieniu, skutkującym utratą ich doniosłości dla życia, co powoduje kryzys; po drugie, przezwyciężenie kryzysu oznacza zwalczenie generowanych przez nauki przesądów oraz wymaga przeprowadzenia autentycznej analizy świadomości jako zadania, któremu ma sprostać fenomenologiczna filozofia.

Problem kryzysu człowieczeństwa zostanie rozpatrzony w niniejszym artykule w postaci dwóch wątków: pierwszy dotyczy trudności związanych $\mathrm{z}$ ujęciem korelacji między podmiotowością i światem oraz zadań fenomenologii jako nauki, która odsłania konstytuujące życie subiektywności transcendentalnej; drugi poświęcony jest koncepcji Lebenswelt („świata życia”), która wiąże się z możliwością przezwyciężenia naturalistycznego sposobu myślenia poprzez zwrot w stronę naiwności świata życia, a ten zwrot ze swej strony otwiera możliwość powrotu do subiektywności transcendentalnej. Akcentując znaczenie badania subiektywności transcendentalnej, która czyni zrozumiałym świat obiektywny, Husserl wiąże tym samym ze swym projektem fenomenologii możliwość transcendentalnego wyjaśnienia nauk oraz przezwyciężenia ogólnego kryzysu, którego efektem jest zarazem odsłonięcie zakrytego $\mathrm{w}$ nastawieniu naturalnym podmiotowego charakteru człowieczeństwa ${ }^{2}$.

Tak więc w niniejszym artykule Husserla fenomenologię odczytujemy pod kątem wątków związanych z ideą kryzysu człowieczeństwa. Wątki te obecne implicite we wczesnym etapie filozofowania kulminują się w Kryzysie nauk europejskich i decydują o wyjątkowości tego dzieła oraz rozstrzygającym znaczeniu fenomenologii jako filozofii transcendentalnej, która jako autentyczna filozofia „czyni wolnym, a nie jedynie badaczem, każdego, kto jest filozoficznie wykształcony"3. Już w początkowym okresie poglądów Husserla wyczuwalna jest predylekcja do namysłu nad korelacją między przedmiotem wiedzy i aktem poznania, która stanowi rdzeń - przedstawionej w Badaniach logicznych krytyki psychologizmu będącego w istocie relatywistycznym przesądem mającym konsekwencje antropologiczne. Radykalizując dociekania związane $\mathrm{z}$ transcendentalnym wyjaśnieniem poznania, Husserl pisze wprost

${ }^{2}$ Zob. P. Łaciak, Anonimowość jako granica poznania w fenomenologii Edmunda Husserla, Katowice 2012, s. 7.

${ }^{3}$ E. Husserl, Die Krisis der europäischen Wissenschaften..., s. 5-6. Cyt. za polskim przekładem Kryzysu... - E. Husserl, Kryzys nauk europejskich i fenomenologia transcendentalna..., s. 9. 
o rzeczywistej naukowej pracy, która uwalnia od przesądów (w szczególności od dogmatyzmu oraz od sceptycyzmu) i podejmowana jest w ramach fenomenologii transcendentalnej. Nie można pominąć faktu, że to właśnie idea przezwyciężenia kryzysu, który polega na zapoznaniu istotowej natury życia świadomości w jej funkcji konstytuowania, stanowi nieusuwalny wątek myśli Husserla (interpretowany również jako krytyczny i etyczno-praktyczny motyw), w którego perspektywie warto odczytywać dzieła tego filozofa. W rozumieniu twórcy fenomenologii prawdziwa podstawa filozofii znajduje się w subiektywności transcendentalnej, bo to wraz z odkryciem tej subiektywności i uwyraźnieniem jej roli w procesie konstytucji ujawnia się znaczenie fenomenologii jako filozofii transcendentalnej.

Widzi się w tym - pisze Husserl - niezbędną reformę pierwotnej fenomenologii konstytutywnej, reformę, dzięki której osiągnie ona dopiero właściwy, filozoficzny wymiar4.

\section{Korelacja: podmiotowość transcendentalna i świat}

W odniesieniu do podejmowanego problemu człowieczeństwa i jego kryzysu warto zaakcentować, że w fenomenologii nie ma refleksji o człowieku rozpatrywanym w sobie i dla siebie. Nie może zatem dziwić fakt, że Husserl nie przeprowadza rozważań stricte antropologicznych. Jego zdaniem antropologizm pozostaje ślepy na wszelkie absolutne ideały, normy oraz teleologiczne idee $^{5}$. Dlatego antropologia znajduje ugruntowanie w fenomenologii, która stanowi filozofię pierwszą.

Według Husserla:

pierwotna fenomenologia rozumiana jako fenomenologia transcendentalna odmawia każdej, jakiegokolwiek rodzaju nauce o człowieku udziału w tworzeniu podstaw filozofii i zwalcza wszelkie zmierzające w tym kierunku próby jako antropologizm i psychologizm ${ }^{6}$.

${ }^{4}$ E. Husserl, Fenomenologia i antropologia, przeł. S. Walczewska, „Archiwum Historii Filozofii i Myśli Społecznej”, t. 32, 1987, s. 333.

${ }^{5}$ Zob. E. Husserl, Filozofia jako ścisła nauka, przeł. W. Galewicz, Warszawa 1992, s. 15.

${ }^{6}$ E. Husserl, Fenomenologia i antropologia..., s. 333. 
Podstawa filozofii nie może znajdować się w człowieku, ponieważ człowiek stanowi element procesu konstytucyjnego zachodzącego w ramach życia transcendentalnego: subiektywność w ramach konstytucji świata uświatawia się $\mathrm{w}$ postaci człowieka i w tej postaci zarazem zapomina o sobie, a to zapomnienie o sobie prowadzi do kryzysu?. W Medytacjach kartezjańskich czytamy:

Z całą oczywistością można powiedzieć jako żyjące w naturalnym nastawieniu Ja, jestem równocześnie i za każdym razem (auch und immer) Ja transcendentalnym, dowiaduję się o tym jednak dopiero przeprowadzając redukcję fenomenologiczną.

Fenomenologia nie jest niczym innym niż rozważaniem umożliwiającym zrozumienie samego siebie jako samoobiektywizacji „ja” transcendentalnego ponieważ, jak stwierdza Husserl:

każdy człowiek „nosi w sobie transcendentalne Ja”, ale nie jako realną część lub jakąś warstwę swojej duszy [...], ale w tej mierze, w jakiej jest on wykazywalną na drodze fenomenologicznej samorefleksji samoobiektywizacją odnośnego transcendentalnego $\mathrm{Ja}^{9}$.

W procesie konstytucji człowiek będący samoobiektywizacją „ja” transcendentalnego jawi się jako nosiciel absolutnej subiektywności konstytuującej świat. W świetle Husserlowskiej idei konstytucji polegającej na tym, że odwołując się do 49 paragrafu pierwszej księgi Idei czystej fenomenologii świat rzeczy transcendentnych pozostaje "całkowicie zdany na świadomość" ${ }^{10}$, transcendentalna podmiotowość ujmowana jest jako warunek zaistnienia świata, a zarazem człowieka jako części świata. Koncepcja „ja” człowieczego („ja” empirycznego), które jest zawsze zarazem „ja” transcendentalnym zakłada dialog z tym, co transcendentne, dialog, którego warunkiem pozostaje świadomość transcendentalna. A ponieważ warunkuje ona możliwość doświadczenia świata, dlatego elementów tych - jak słusznie zauważa Dan

${ }^{7}$ P. Łaciak, Anonimowość jako granica poznania..., s. 27-28.

${ }^{8}$ E. Husserl, Medytacje kartezjańskie $z$ dodaniem uwag krytycznych Romana Ingardena, przeł.

A. Wajs, Warszawa 1982, s. 20.

${ }^{9}$ E. Husserl, Die Krisis der europäischen Wissenschaften..., s. 190.

${ }^{10}$ E. Husserl, Idee czystej fenomenologii i fenomenologicznej filozofi, księga pierwsza, przeł.

D. Gierulanka, Warszawa 1967, s. 158. 
Zahavi - „nie wolno pojmować w separacji od siebie”"11. Komentator ten stwierdza następująco:

mówić o transcendentalnej podmiotowości jako o bycie konstytuującym i nadającym znaczenie oraz mówić o przedmiotach ukonstytuowanych przez tę podmiotowość i zależnych od niej znaczy, formalnie rzecz ujmując, mówić o strukturze podmiotowość-świat jako schemacie transcendentalnym, w ramach którego przedmioty mogą się zjawiać12.

Nierozerwalna korelacja świadomości i świata ujawnia się dopiero dzięki dokonaniu transcendentalnej epoché.

Przecież właśnie dzięki epoche - pisze Husserl - staje się widoczne, że dopiero w życiu Ego apercepcja „człowiek” uzyskuje swój sens istnienia wewnątrz uniwersalnej apercepcji świat ${ }^{13}$.

W innym miejscu czytamy:

Poprzez transcendentalną epoche dostrzegam - stwierdza dalej filozof - [...] że wszystko, co istnieje w świecie - dotyczy to również istnienia mojego jako człowieka - jest dla mnie czymś istniejącym (Daseiendes), jedynie jako treść pewnej apercepcji doświadczającej w modus pewności istnienia. Jako transcendentalne Ego jestem dokonującym tej apercepcji, przeżywającym ją Ja. Jest ona dzianiem się we mnie, skrywającym się co prawda przed refleksją, dzianiem się, w którym przede wszystkim konstytuują się dla mnie jako istniejące świat i ludzka osoba ${ }^{14}$.

Z kolei w Medytacjach kartezjańskich Husserl pisze w tym kontekście, że świadomość i byt jako dwa przynależące do siebie elementy stanowią jedność, która charakteryzuje subiektywność transcendentalną:

momenty [te - A. W.] przynależące do siebie [...] można określić również jako stanowiące coś konkretnie jednego (jednego w jedynej absolutnej

${ }^{11}$ D. Zahavi, Fenomenologia Husserla, przeł. M. Święch, Kraków 2012, s. 100.

12 Tamże, s. 101.

${ }^{13}$ E. Husserl, Fenomenologia i antropologia..., s. 341.

${ }^{14}$ Tamże, s. 342. 
konkrecji (Konkretion): konkrecji, która charakteryzuje subiektywność transcendentalną ${ }^{15}$.

Powtórzmy, w świetle tej jedności okazuje się, że w procesie konstytucji świata „ja" dokonuje zarazem apercepcji samego siebie, uświatawiając się. Ponieważ, jak pisze autor Medytacji...:

ukonstytuowawszy istniejący dla mnie świat jako fenomen i korelat, jako korelat, którego konstytucję [...] nadal jak owo ego realizuję, dokonałem jednocześnie - jako człowiecze, osobowe Ja [...] pewnego rodzaju apercepcji siebie samego, apercepcji [...] nadającej mi charakter czegoś będącego w świecie (verwelt-lichende) ${ }^{16}$.

Okazuje się więc, że „ja”, tożsame wśród płynącego strumienia świadomości, samo kształtuje się w procesie własnej konstytucji i pojmuje siebie jako byt światowy. W rozumieniu twórcy fenomenologii:

ego samo jest czymś, co istnieje dla siebie w ciągłej oczywistości, a więc czymś, co nieprzerwanie konstytuuje siebie samo jako coś istniejącego ${ }^{17}$.

Kształtując swe ego w rezultacie konstytucji świata, niejako odnajduje ono „swój własny świat jako coś wewnątrz (drinnen) siebie”" ${ }^{18}$. Wszak jak również w Medytacjach kartezjańskich czytamy:

ja człowiecze (Ja psychofizyczne) jestem [...] ukonstytuowany jako człon świa$t a$, ukonstytuowany wraz z innymi mnogimi członami, które stanowią pewne Poza-mna; ale to ja sam konstytuuję to wszystko w mojej duszy i intencjonalnie w sobie unoszę ${ }^{19}$.

W swym ostatnim dziele Husserl podkreśla, że dzięki transcendentalnemu badaniu odsłonięte zostaje to, co stanowi istotę człowieczeństwa. Dzięki redukcji ujawnia się istotny rys świadomości transcendentalnej, która $\mathrm{z}$ jednej strony pozostaje sferą indywidualną, konkretną, czyli moją, z drugiej nato-

\footnotetext{
${ }^{15}$ E. Husserl, Medytacje kartezjańskie..., s. 123.

16 Tamże, s. 146.

17 Tamże, s. 94.

18 Tamże, s. 145.

19 Tamże, s. 144.
} 
miast strony, jako czynnik konstytuujący, organizuje oraz nadaje sens wszelkim przedmiotom i dziedzinom przedmiotowym.

Filozofię transcendentalną - pisze Husserl - wypracowaną w sposób czysty i prowadzącą rzeczywistą, naukową pracę dostrzec potrafię jedynie w transcendentalnej albo konstytutywnej fenomenologii. [...] Tradycyjne przesądy działają jak klapki na oczach i nie pozwalają przeniknąć jej rzeczywistego sensu ${ }^{20}$.

Fenomenologia pojmowana jako praca myślenia wiąże się z ujawnianiem przeświadczeń, jakie żywimy w ramach nastawienia naturalnego. W Kryzysie... czytamy, że

naturalne, obiektywne życie w świecie stanowi jedynie szczególny modus stale konstytuującego świat życia transcendentalnego tego rodzaju, że podmiotowość transcendentalna, żyjąc $\mathrm{z}$ dnia na dzień, nie uświadamia sobie tych konstytucyjnych horyzontów i nigdy nie może ich sobie uzmysłowić ${ }^{21}$.

Warto w tym kontekście odwołać się do słów Jana Patočki, który w odniesieniu do sfery życia nastawienia naturalnego pisze, że chodzi tu o „świat subiektywny, ale nieświadomy swojej subiektywności”22, czyli, posługując się terminologią Husserla, o świat w sensie Lebenswelt.

\section{„Świat życia” jako powrót do subiektywności transcendentalnej}

Husserl nie przeciwstawia świadomości światu i tym samym w fenomenologii nie dochodzi do przeciwstawienia światowego, ludzkiego „ja” podmiotowości transcendentalnej, wręcz przeciwnie: akcentuje nierozerwalny związek świata i doświadczenia świata. Ten związek świadomości i świata w późniejszych tekstach Husserla wyraża pojęcie świata przeżywanego.

\footnotetext{
${ }^{20}$ E. Husserl, Fenomenologia i antropologia..., s. 337.

${ }^{21}$ E. Husserl, Die Krisis der europäischen Wissenschaften..., s. 179. Cyt. za polskim przekładem fragmentów Kryzysu... - E. Husserl, Wybór pism, przeł. S. Walczewska, [w:] K. Święcicka, Husserl, Warszawa 2005, s. 186.

${ }^{22}$ J. Patočka, Filozofia kryzysu nauki według Edmunda Husserla i jego koncepcja fenomenologii »świata przeżywanego«, przeł. J. Zychowicz, [w:] Świat przeżywany. Fenomenologia i nauki społeczne, Warszawa 1993, s. 30.
} 
W Kryzysie nauk europejskich... Husserl przedstawia ideę świata życia (Lebenswelt). Świat życia (Lebenswelt), o który chodzi Husserlowi nie jest na pewno światem nauk przyrodniczych, lecz - jak określił go J.-F. Lyotard „jest [on] zbiorem czy ideą w sensie kantowskim tego wszystkiego, co obejmuje i co może obejmować świadomośćn" ${ }^{3}$. Czyniąc punktem wyjścia swych rozważań Lebenswelt, Husserl stawia przed fenomenologią zadanie odsłaniania świata, który pozostaje zakryty na skutek naturalistycznych przesądów, jak również intelektualnych modyfikacji. Lebenswelt jest światem codziennego życia, danym w nastawieniu personalistycznym, które jest nastawieniem par excellence naturalnym.

Świat - pisze w Doświadczeniu i sadzie twórca fenomenologii - jako świat istniejacy jest uniwersalnym biernym przeddaniem wszelkiej aktywności sądzenia, wszelkiego wkraczającego zainteresowania teoretycznego ${ }^{24}$.

Rozwijając ideę „świata życia”, Husserl akcentuje jedność świata i subiektywności, tak że subiektywność jako transcendentalny warunek konstytucji jest zarówno życiem urzeczywistniającym się w świecie, jak i życiem, obejmującym świat i człowieka. Warto przy okazji nadmienić mediacyjny charakter świata przeżywanego, który dostrzega J. Rolewski, stwierdzając, że świat życia „pełni - w przekonaniu Husserla - funkcję pewnego medium pomiędzy nauką a ostatecznym źródłem wszelkiego sensu, czyli ego transcendentalnym"25.

W ramach fenomenologii świata przeżywanego Husserl wyróżnia dwa kroki. Po pierwsze, wyłączenie świata nauki i powrót do świata przeżywanego. Po drugie, zwrot od świata przeżywanego do subiektywnych dokonań, z których czerpie on sens ${ }^{26}$. Zaprezentujemy najpierw rozważania związane z pierwszym krokiem. Husserl rozwija ideę świata przeżywanego (poprzedzającego wszelką teoretyczno-naukową refleksję) w rezultacie rozważań nad relacją nauki, filozofii i życia. Motyw przeciwstawienia świata życia naukowemu obrazowi rzeczywistości wiąże się ściśle z celem fenomenologii, jaki wyznaczył jej Husserl oraz możliwością przezwyciężenia kryzysu. Właśnie

${ }^{23}$ J.-F. Lyotard, Fenomenologia, przeł. J. Migasiński, Warszawa 2000, s. 59.

${ }^{24}$ E. Husserl, Doświadczenie i sąd. Badania nad genealogia logiki, przeł. B. Baran, Warszawa 2013, s. 40.

${ }^{25}$ J. Rolewski, Rozum, nauka, świat przeżywany. Studium filozofii późnego Husserla, Toruń 1999, s. 57.

${ }^{26}$ E. Husserl, Doświadczenie i sąd..., s. 57. 
bowiem z powstaniem filozofii oznaczającym zdaniem Husserla zrewolucjonizowanie całego sposobu bycia człowiekiem dokonuje się zarazem zrewolucjonizowanie kultury i „dziejowości, która teraz jest dziejami stawania się człowieczeństwa skończonego człowieczeństwem nieskończonych zadań”27. Fenomenologia transcendentalna i realizowany w jej ramach postulat powrotu do świata przeżywanego stanowią reakcję na ogólny kryzys człowieczeństwa, kryzys nauk historycznych oraz przyrodniczych będący częścią kryzysu kultury. Kryzys ten jest w istocie kryzysem racjonalizmu, który uległ ułudzie obiektywizmu i naturalizmu. W odniesieniu do tej sytuacji, niebezpiecznej nie tylko dla nauki, lecz przede wszystkim dla człowieczeństwa i kultury, Husserl, przeprowadzając krytykę nauk pozytywnych, pokazuje, że aby przywrócić nauce i filozofii jej rolę, należy powrócić do zapomnianego źródła oraz pytań fundamentalnych dla dziejów ludzkości. Według Husserla nauki sprowadzające człowieka do samego tylko faktu odwracają się od pytań rozstrzygających dla losów ludzkości ${ }^{28}$.

Kryzys nauki - wyjaśnia - nie znaczy przecież nic innego jak tylko to, że problematyczna stała się jej autentyczna istota, cały jej sposób stawiania sobie zadań i wypracowywania odpowiedniej dla nich metody. Odnosić się to może do filozofii, której w naszych czasach zagraża sceptycyzm, irracjonalizm czy mistycyzm ${ }^{29}$.

Poddając krytyce wszelkie postępowanie obiektywno-naukowe zapoznające to, co źródłowe, autor Kryzysu... zwraca jednocześnie uwagę na potrzebę przewartościowania celów oraz ponownego rozpatrzenia kierunku rozwoju nauk. Sięgając w swym ostatnim dziele genezy myśli filozoficznej, Husserl przeprowadza rzetelną analizę przyczyn kondycji nauk, kondycji rozumu tej kultury, która ponosi odpowiedzialność za utratę jedności nauki i filozofii $\mathrm{z}$ naturalnym światem życia. Analizując przyczyny kryzysu i jego symptomy, autor Kryzysu... daje się poznać jako myśliciel szczególnie uwrażliwiony na „separację nauk od tego, co konkretne”, na to, że w ramach analiz i badań

\footnotetext{
${ }^{27}$ E. Husserl, Die Krisis der europäischen Wissenschaften..., s. 325. Cyt. za: E. Husserl, Kryzys europejskiego człowieczeństwa a filozofia, przeł. J. Sidorek, Warszawa 1993, s. 24.

${ }^{28} \mathrm{Na}$ temat drogi Husserla przez krytykę nauk pozytywnych zob. J. Czarkowski, Filozofia czystej świadomości. Redukcja, refleksja, czysta świadomość w fenomenologii transcendentalnej Edmunda Husserla, Toruń 1994, s. 75-79.

${ }^{29}$ E. Husserl, Die Krisis der europäischen Wissenschaften..., s. 1. Cyt. za polskim przekładem Kryzysu... - E. Husserl, Kryzys nauk europejskich..., s. 5.
} 
nie uwzględniają one najbardziej istotnych zagadnień dotyczących ludzkiego życia, kwestii związanych z jego sensem i znaczeniem ${ }^{30}$.

Zwrot Husserla do świata przeżywanego - jak już wcześniej zaznaczyliśmy - jest w istocie powrotem do transcendentalnej subiektywności, powrotem, który Husserl realizuje w ramach kroku drugiego. Po wyłączeniu świata nauki, realizuje on zwrot od świata przeżywanego do transcendentalnej podstawy, z której ów świat czerpie sens. Autor Kryzysu... stwierdza wprost, że świat przeżywany jest światem „względnym w stosunku do nadającej mu sens subiektywności" ${ }^{31}$. Chodzi tu o świat konkretnych osób, ich zamiarów, dokonań i motywacji.

W tym ujęciu - czytamy w ostatniej pracy Husserla - idzie zatem nie o taki świat, jaki rzeczywiście jest, lecz o świat, który obowiązuje dla danych osób, o świat im się zjawiający, z takimi cechami, z jakimi im się zjawia. Pytamy o to, jak ci ludzie jako osoby zachowują się w działaniu i przeżywaniu - jak są motywowani do swych specyficznych, osobowych aktów postrzegania, przypominania, myślenia, oceniania, planowania, lęku i przerażenia, obrony, atakowania itd. Osoby są motywowane tylko przez to, co sobie uświadamiają, i w sposób, w jaki - dzięki zmysłom - sobie to uświadamiają, w jaki to dla nich obowiązuje lub nie itd. ${ }^{32}$.

Zapewniając możliwość odniesienia obiektywno-naukowego świata do świata przeżywanego, a świata przeżywanego do jego transcendentalnej podstawy, fenomenologia pozostaje rozważaniem, które ma na celu transcendentalne wyjaśnienie tego, co naturalnie oczywiste. Husserl pokazuje, że świat, który zjawia się człowiekowi, zyskuje swe znaczenie ze względu na subiektywne dokonania i warunki związane z procesem konstytucji. Wpisując się w pokantowską tradycję transcendentalnofilozoficzną, twórca fenomenologii dąży - jak zauważa Karen Gloy - do wykazania, iż:

przedmioty świata, które przyjmujemy w naszym naturalnym nastawieniu za będące w sobie i niezależne od nas, należy wyjaśnić za pomocą czynności świa-

${ }^{30}$ Zob. R. Bernet, I. Kern, E. Marbach, An Introduction to Husserlian Phenomenology, Evanston-Illinois 1993, s. 223.

${ }^{31}$ E. Husserl, Die Krisis der europäischen Wissenschaften..., s. 310. Cyt. za polskim przekładem fragmentów Kryzysu... - E. Husserl, Nastawienie nauk przyrodniczych i humanistycznych, [w:] Fenomenologia i socjologia. Zbiór tekstów, red. Z. Krasnodębski, Warszawa 1989, s. 71.

32 Tamże, s. 296. Cyt. za polskim przekładem fragmentów Kryzysu... - E. Husserl, Nastawienie nauk przyrodniczych i humanistycznych..., s. 56. 
domości, ponieważ są one wytworami, czy też korelatami świadomości i poza nią nie posiadają żadnej realności ${ }^{33}$.

\section{W konsekwencji fenomenologia oznacza}

cofnięcie się od tej uniwersalnej, swoiście historycznej, zrelatywizowanej do osoby refleksji nad światem, odbywającej się na gruncie zastanego świata, na grunt absolutny, na grunt subiektywności transcendentalnej ${ }^{34}$.

Pierwotna relacja świata i podmiotowości transcendentalnej jest relacją teleologiczną. Teleologia pozostaje w związku z krytyką naukowego dążenia do naturalizacji świadomości i naturalizacji wszelkich idei. Ta problematyka pojawia się wszędzie tam, gdzie mowa o kryzysie. To właśnie idea teleologii jest kluczem do zrozumienia związku między subiektywnością, jej antropologicznym wcieleniem, filozofią i nauką. Rozwiązanie tkwi w ponownym postawieniu problemu podmiotowości. O ile nauki same w sobie nie mają wiele do powiedzenia na temat ludzkiego doświadczenia, o tyle - zorientowana teleologicznie - fenomenologia podkreśla związek świata i jego doświadczenia. Doniosłość teleologicznego wymiaru podmiotowości uwyraźnia sam autor Kryzysu..., twierdząc, że

jeśli człowiek staje się zagadnieniem „metafizycznym”, zagadnieniem specyficznie filozoficznym, wówczas ulega problematyzacji on jako istota rozumna oraz jego historia, wówczas chodzi o „sens”, o rozum w historii ${ }^{35}$.

W odniesieniu do Husserlowskiej teleologii chodzi o ideę nigdy do końca nieurzeczywistnialną, o rozum ukryty w dziejach, rozum, którego ujawnianie wieńczy fenomenologia odkrywająca transcendentalną subiektywność, jaką nosi w sobie każdy człowiek.

Rozum - pisze Husserl - nie jest żadną przygodną, faktyczną zdolnością, nazwą dla możliwych przypadkowych faktów, lecz przeciwnie,

${ }^{33}$ K. Gloy, Wprowadzenie do filozofii świadomości. Problematyka i historia zagadnienia świadomości oraz samoświadomości, przeł. T. Kubalica, Kraków 2009, s. 233.

${ }^{34}$ E. Husserl, Die Krisis der europäischen Wissenschaften..., s. 312-313. Cyt. za polskim przekładem fragmentów Kryzysu... - E. Husserl, Nastawienie nauk przyrodniczych i humanistycznych..., s. 74 .

${ }^{35}$ Tamże, s. 7. Cyt. za polskim przekładem fragmentów Kryzysu... - E. Husserl, Kryzys nauk europejskich..., s. 11. 
uniwersalną formą istotową charakteryzującą strukturę transcendentalnej subiektywności w ogóle ${ }^{36}$.

W swej ostatniej pracy, czyli w Kryzysie... Husserl pisze o historycznym procesie ujawniania się uniwersalnego rozumu wrodzonego ludzkości ${ }^{37}$ i przedstawia trzy poziomy stawania się rozumu odpowiadające poziomom historyczności. Wskazując pierwszy poziom, pisze o historyczności w ogóle jako miejscu kultury i tradycji. Kolejny poziom to poziom europejskiej kultury rozumianej jako projekt teoretyczno-filozoficzny. Prezentując poziom najwyższy, pisze z kolei o przemianie filozofii w fenomenologię. Kryzys myślenia o człowieku wiąże się z kolei z tym, że na skutek pozytywistyczno-naturalistycznego zniekształcenia zafałszowany zostaje obraz podmiotowości. Paradoksalnie, bujnemu rozkwitowi nauk towarzyszy zafałszowanie myślenia o człowieku. Wraz z powstaniem filozofii rozpoczyna się proces odsłaniania telosu (rozumu), zdemaskowane zostają przyczyny zafałszowania i ograniczenia nauk. Zafałszowanie to doprowadza do porzucenia teleologizmu na rzecz wypaczonego racjonalizmu. Zapoznanie teleologizmu oznacza, że racjonalizm nabiera wypaczonego charakteru generującego przesądy, takie jak naturalizm i historyzm. Ukazując związek między rzeczywistością światową i transcendentalną, Husserl akcentuje teleologiczną jedność, jedność tego, co empiryczne i tego, co transcendentalne. Kwestię tę wyjaśnia Stanisław Judycki następującymi słowy:

rzeczywistość - transcendentalna i światowa - jawi się jako jedność celowościowo ukierunkowanego historycznego życia i rozwoju. Teleologia staje się rozważaniem o celowościowym rozwoju transcendentalnego absolutu i powstającego dzięki niemu bytu ${ }^{38}$.

W ramach konkluzji należy podkreślić, że przypomnienie o celowościowo zorientowanym życiu podmiotowości zyskuje znaczenie uzdrowienia $\mathrm{z}$ duchowego zaślepienia. Rozumienie człowieczego „ja” oznacza dla Husserla rozumienie:

\footnotetext{
${ }^{36}$ E. Husserl, Medytacje kartezjańskie..., s. 81.

${ }^{37}$ E. Husserl, Die Krisis der europäischen Wissenschaften..., s. 14. Cyt. za polskim przekładem fragmentów Kryzysu... - E. Husserl, Kryzys nauk europejskich..., s. 18.

${ }^{38}$ S. Judycki, Intersubiektywność i czas. Przyczynek do dyskusji nad późna faza pogląów Edmunda Husserla, Lublin 1990, s. 216.
} 
że być człowiekiem, znaczy być teleologicznym, być powinnością i że ta teleologia objawia się we wszystkich czynach i zamierzeniach Ja, że (jako ludzkość) może ona przez rozumienie siebie poznać we wszystkim ten apodyktyczny telos i że to poznanie poprzez ostateczne rozumienie siebie znaczy tyle, co rozumienie siebie według zasad a priori - rozumienie siebie w postaci filozofi ${ }^{39}$.

Dzięki filozofii urzeczywistnia się telos człowieczeństwa.

Jako [...] apodyktyczne Ja - pisze niemiecki filozof - jestem wobec istnienia świata czymś w sobie wcześniejszym. [...] Oczywiście tylko jako to Ja mogę ostatecznie wziąć odpowiedzialność za istnienie świata, mogę przeprowadzić, o ile w ogóle mogę, naukę z całkowitą odpowiedzialnością ${ }^{40}$.

Fenomenologia Lebenswelt realizowana w efekcie namysłu nad znaczeniem filozofii i nauki dla ludzkiego życia, kryje w sobie znaczenie „uniwersalnej przemiany sensu", przeobrażenia człowieczeństwa ${ }^{41}$. Warto - odwołując się do interpretacyjnych komentarzy - zaakcentować, że twórca fenomenologii, daje się przy tym poznać jako lekarz skupiony na uleczeniu schorzeń danego czasu ${ }^{42}$. Sam Husserl w Kryzysie... dobitnie stwierdza, iż

chodzi o to, by na nowo ukształtować etycznie nie tylko siebie samego, lecz także cały świat, polityczne i społeczne istnienie człowieka, a wszystko to wychodząc od wolnego rozumu, od intuicji uniwersalnej filozofii ${ }^{43}$.

Okazuje się więc, że to, co początkowo było dla Husserla fundamentalnym problemem $\mathrm{z}$ zakresu teorii nauki, przybrało - na co zwracają uwagę komentatorzy - w jego rozważaniach postać „problemu uniwersalnego bytu i prawdy" ${ }^{4}$.

${ }^{39}$ E. Husserl, Filozofia jako zdobywanie samowiedzy przez ludzkość, przeł. Z. Krasnodębski, „Studia Filozoficzne” 1984, nr 2, s. 179.

${ }^{40}$ Tenże, Fenomenologia i antropologia..., s. 339.

${ }^{41}$ Tenże, Die Krisis der europäischen Wissenschaften..., s. 12. Cyt. za polskim przekładem fragmentów Kryzysu... - tenże, Kryzys nauk europejskich..., s. 16.

${ }_{2}$ Zob. na ten temat: J. Dodd, Crisis and Reflection. An Essay on Husserl's Crisis of the European Sciences, Dordrecht 2004, s. 48.

${ }^{43}$ E. Husserl, Die Krisis der europäischen Wissenschaften..., s. 6. Cyt. za polskim przekładem fragmentów Kryzysu... - tenże, Kryzys nauk europejskich..., s. 10.

${ }^{44}$ R. Bernet, I. Kern, E. Marbach, An Introduction to Husserlian phenomenology ..., s. 220. 


\section{Bibliografia}

Bernet R., Kern I., Marbach E., An Introduction to Husserlian Phenomenology, Evanston-Illinois 1993.

Czarkowski J., Filozofia czystej świadomości. Redukcja, refleksja, czysta świadomość w fenomenologii transcendentalnej Edmunda Husserla, Toruń 1994.

Dodd J., Crisis and Reflection. An Essay on Husserl's Crisis of the European Sciences, Dordrecht 2004.

Gloy K., Wprowadzenie do filozofii świadomości. Problematyka i historia zagadnienia świadomości oraz samoświadomości, przeł. T. Kubalica, Kraków 2009.

Husserl E., Doświadczenie i sąd. Badania nad genealogia logiki, przeł. B. Baran, Warszawa 2013.

Husserl E., Die Krisis der europäischen Wissenschaften und die transzendentale Phänomenologie. Eine Einleitung in die phänomenologische Philosophie, hrsg. von W. Biemel, [in:] Husserliana - Edmund Husserl, Gesammelte Werke. Bd. 6, Den Haag 1962. Cyt. za polskim przekładem fragmentów Kryzysu...: 1. Husserl E., Kryzys nauk europejskich i fenomenologia transcendentalna, przeł. S. Walczewska, Toruń 1999; 2. Husserl E., Nastawienie nauk przyrodniczych i humanistycznych, [w:] Fenomenologia i socjologia. Zbiór tekstów, red. Z. Krasnodębski, Warszawa 1989; 3. Husserl E., Kryzys europejskiego człowieczeństwa a filozofia, przeł. J. Sidorek, Warszawa 1993; 4. Husserl E., Wybór pism, przeł. S. Walczewska, [w:] K. Święcicka, Husserl, Warszawa 2005.

Husserl E., Fenomenologia i antropologia, przeł. S. Walczewska, „Archiwum Historii Filozofii i Myśli Społecznej”, t. 32, 1987.

Husserl E., Filozofia jako ścisła nauka, przeł. W. Galewicz, Warszawa 1992.

Husserl E., Filozofia jako zdobywanie samowiedzy przez ludzkość, przeł. Z. Krasnodębski, „Studia Filozoficzne” 1984, nr 2.

Husserl E., Idee czystej fenomenologii i fenomenologicznej filozofii, księga pierwsza, przeł. D. Gierulanka, Warszawa 1967.

Husserl E., Medytacje kartezjańskie z dodaniem uwag krytycznych Romana Ingardena, przeł. A. Wajs, Warszawa 1982.

Judycki S., Intersubiektywność i czas. Przyczynek do dyskusji nad późna fazą pogladów Edmunda Husserla, Lublin 1990.

Lyotard J.-F., Fenomenologia, przeł. J. Migasiński, Warszawa 2000.

Łaciak P., Anonimowość jako granica poznania w fenomenologii Edmunda Husserla, Katowice 2012.

Patočka J., Filozofia kryzysu nauki według Edmunda Husserla i jego koncepcja fenomenologii »świata przeżywanego", przeł. J. Zychowicz, [w:] Świat przeżywany. Fenomenologia i nauki społeczne, Warszawa 1993. 
Rolewski J., Rozum, nauka, świat przeżywany. Studium filozofii późnego Husserla, Toruń 1999.

Zahavi D., Fenomenologia Husserla, przeł. M. Święch, Kraków 2012.

\author{
Abstract \\ Phenomenological Understanding of Subjectivity \\ and the Crisis of Humanity
}

The aim of article is to show that Husserl's diagnosis of crisis, especially crisis of science is connected with consequences cause the crisis of European humanity. Crisis of European humanity is permanent motive of Husserl's philosophy and consist on omitting essence of the subjectivity, that is its transcendental character. In relation to the idea of crisis Husserl showed that sciences remain in the blindness resulting in loss of the significance for the human life, leading to general crisis. Possibility of overcoming the crisis means freeing from prejudices and requires carrying out an analysis of consciousness taken as a special phenomenological task. In the article author present the problem of crisis in two steps. The first step is connected with considerations about problems concerning correlation between subjectivity and world; the second one refer to the idea of Lebenswelt and possibility of overcome of naturalistic way of thinking.

Key words: Edmund Husserl, phenomenology, subjectivity, human, world 